\title{
US Taiwan Policy during the George W. Bush Administration (2001-2009)
}

\author{
Ben Lian Deng
}

Vínculo Institucional: Doutorando em Economia Política Internacional pela Universidade Federal do Rio de Janeiro (UFRJ)

\begin{abstract}
:
The purpose of this article is to analyze the United States' (US) Taiwan policy during the George W. Bush administration (2001-2009)—specifically, how Washington actively opposed Taiwanese independence during this period. After the Korean War (1950), the US's official policy on Taiwan was to "neutralize" and prevent war across the Taiwan Strait, thereby maintaining the status quoin the region. During the 1950's and 1960's, the US successfully prevented Chinese attempts to invade Taiwan. However, the dynamic of the cross-strait relations changed drastically in the 1990's, following Taiwan's political liberalization and the emergence of the Taiwanese independence movement. During the George W. Bush administration (2001-2009), Taiwan was ruled by the pro-independence Chen Shui-bian (2000-2008), which increased cross-strait tensions. In order to satisfy its own geopolitical interests, the US actively denied support to this movement, boycotting Chen's attempts to declare Taiwan's independence. This paper concludes that the core of the US's Taiwan policy is to prevent alteration of the status quo or threat of war in the region, while using the "Taiwan Card" as a bargaining chip in bilateral negotiations with China.
\end{abstract}

Keywords:

China, Taiwan, US-Taiwan Relations

\section{Resumo:}

O objetivo deste artigo é analisar a política americana em relação a Taiwan durante o governo de George W. Bush (2001-2009), e de qual forma Washington se opôs ativamente ao movimento de independência de Taiwan durante este período. Desde a eclosão da Guerra da Coréia (1950), a política oficial dos Estados Unidos da América (EUA) para Taiwan foi de "neutralizar" e impedir qualquer guerra no Estreito de Taiwan, mantendo o status quo na região. Durante os anos 50 e 60, os EUA impediram com 


\section{NEIBA}

\section{8}

sucesso qualquer tentativa da China de invadir Taiwan. No entanto, a dinâmica das relações através do Estreito mudou drasticamente desde os anos 90, após a liberalização política em Taiwan, e o surgimento do movimento de independência de Taiwan. Durante o governo de George W. Bush (2001-2009), Taiwan foi governada pela pró-independência Chen Shui-bian (2000-2008), que elevou drasticamente as tensões através do Estreito. A fim de satisfazer seus próprios interesses geopolíticos, os EUA negaram ativamente o apoio a este movimento, e boicotaram as tentativas de Chen de declarar a independência de Taiwan. $O$ artigo conclui que a principal política dos EUA em relação a Taiwan é impedir qualquer alteração do status quo, que pudesse levar a uma guerra na região, e a importância do "Taiwan Card" como objeto de barganha dos EUA, para negociar questões bilaterais com a China.

\section{Palavras-chaves:}

China, Taiwan, Relações EUA-Taiwan 


\section{NEIBA}

\section{Introduction}

Between the 1950's and 1980's, the source of crossstrait tensions between Taiwan and Mainland China was ideological in nature, withthe Chinese Communist Party (CCP)—which won the Chinese Civil War and founded the People's Republic of China (PRC) in Mainland China in 1949on one side. On the other side was the Kuomintang (KMT, commonly known as Chinese Nationalist Party), who ruled Mainland China until the communist victory in 1949, when it transferred the central government headquarters of the ROC (Republic of China) to Taiwan, ruling from the island since then. Duringthis period, both sides proclaimed themselves to be the "sole legal government of China", denying the other'slegitimation. In addition, the PRC tried to invade Taiwan on two occasions, during the First Taiwan Strait Crisis (1954-1955) and then during the Second Taiwan Strait crisis (1958). On both occasions, Washington intervened to preserve the status quo in the region (TSAl, 2009, p. 180194).

Nevertheless, since political liberalization of the ROCin the late 1980's, the dynamic of cross-strait relations between Taiwan and China changed drastically. The source of cross-strait tensions changed with the emergence of the Taiwanese independence movement, a political movement in Taiwan that denied the Chinese national identity defended by the KMT and denied any Chinese right to rule Taiwan, including the ROC itself. The independence movement instead aimed to establish the "Republic of Taiwan", led by the opposition Democratic Progressive Party (DPP), established in 1986. Since then, Taiwan didn't claim itself anymore as the "sole legitimate government of whole China", but an independent state from China. During the 1990's, the then chairman of the KMT and president of the ROC, Lee Teng-hui, who secretly supported Taiwanese independence, initiated a campaign for the return of the ROC to the UN. He was promptly accused by Peking of promoting independence, resulting in the Third Taiwan Strait Crisis (1995-96). Nevertheless, Washington once again interfered in Taiwan in order to maintain the status quo (TSAI, 2009, p. 197-204).

To this day, the PRC claims itself to be the only legal government of all of China, with Taiwan being "an inalienable part of China", thus posing a constant threat of war in the event that Taiwan tries to declare independence or refuses to unify indefinitely. Due to the geostrategic importance of the island for the PRC's security, and the political importance of annexing Taiwan, Peking's authorities refuse to flexibilize the terms of political negotiations, insisting that negotiations must be carried out under the "One Country, Two Systems" formula, which is refused by both KMT and DPP (TAIWAN AFFAIRS OFFICE, 2003). The political deadlock grew unsustainable once the PRC emerged as a political and military superpower, threating the sovereignty of the ROC.

On the other hand, historically, the US has played an important role in the Taiwan Strait since the 1950's, preventing any miscalculation by either side that could result in a war. The ROC plays an important role in American foreign policy in East Asia, in the sense of preventingattempts bythe PRC to expand its military or political influence outside of mainland Asia. The maintenance of Taiwan under the American sphere of influence, is important his geopolitical interest in maintaining the Pax Americana in the region. After Chen Shui-bian of the DPP was elected president of the ROC in 2000, cross-strait tensions increased drastically, forcing Washington to intervene once again. The study the American policy towards Taiwan during this period (20012009), is extremely important to understand the "ambiguity" of the US relations with the PRC and the ROC (KAN, 2009; TSAI, 2009, p. 180-189).

The purpose of this article is to analyze how American diplomacy acted against the interests of Taiwan, according to a policy of maintaining the long-term status quo. The first part analyzes the origin of the US's Taiwan 


\section{NEIBA}

policy. The second part analyses the initial supportive stance adopted by the Bush administration (2001) toward Taiwan. The third part analyses Washington's concerns regarding growing independence activities in Taiwan (2002-2003). The forth part analyses America's warning to the DPP administration (2004-2005). The fifth part analyses America's retaliation and the collapse of the DPP (20062008). Finally, the paper concludes with general reflectionson the US's Taiwan policy during the Bush administration.

\section{The Origins of the US's "One China Policy" (1971-2000)}

Since the reallocation of the central government of the ROC from mainland China to Taiwan in 1949, and the outbreak of the Korean War in 1950, the US government hasofficially adopteda policy of "neutralizing "the Taiwan Strait, with the ultimate objective of preventing communist expansion in Asia. During this period, due to Taiwan's geostrategic importance to Washington, the US actively maintained the status quo in the Taiwan Strait, preventing attempts by the PRC to invade Taiwan and attempts by Chiang Kai-shek in Taiwan to "recover" the mainland. Washington provided military, political and financial support to the KMT regime in Taiwan, and diplomatic support in the international community, suchthat even after it had lost all of mainland China, Taipei retained an official position as the "sole legal representative of China" in the United Nations (UN) until 1971.

Nevertheless, the US's unconditional support for Taipei changed drastically beginning in the 1970s, due to several unfavorable geopolitical changes for the US in the region. In order to guarantee PRC support's inconfronting Soviet influence in East Asia, the US began to use Taiwan as a bargain chip whenever Washington sought Peking's support or to counterbalance Peking's influence. Since then, triangular relations between the US-ROC-PRC was based on strategic ambiguity, via which Washington was able to maintain the status quo-i.e., two sovereign states separated by the Taiwan Strait. Onseveral occasions, Washington played the "Taiwan card" to please the Peking during the 1970's and 1980's, to guarantee Peking's support against the Soviet threat.

In 1971, Washington announced that it would visit Peking to "seek normalization of relations", and it indirectly supported the replacement of the ROC by the PRC in the UN in the same year, leaving the ROC in an unprecedented condition as an unrecognized country within the international community. In the First US-PRC Joint Communique (1972), Washington promised to withdraw gradually American troops from Taiwan. In 1979, the Carter administration announced the Second US-PRC Joint Communique, in which the US officially severed diplomatic relations with the $\mathrm{ROC}$, recognizing the $\mathrm{PRC}$ as the "sole legal government of China", and thereby abrogating the USROC Mutual Defense Treaty of 1955. In 1982, after Peking protested US arms sales to Taiwan-even after the severance of diplomatic relations between the US and the ROCWashington announced the Third US-PRC Joint Communique, in which the US government promised to reduce gradually arms sales to Taiwan (TSAI, 2009, p. 191200).

Nevertheless, these pro-PRC policies were accompanied by several measures to counterbalance America's concessions to Peking and maintain ROC sovereignty in Taiwan and the status quo in the Taiwan Strait. In 1979, after the severance of diplomatic relations between the US and the ROC, the Carter administration signed the "Taiwan Relations Act" (TRA, Public Law 96-8), by which Washington established informal relations with the ROC and restored the US's commitment toTaiwan's security against external aggression. In 1982, before the announcement of the Third US-PRC Joint Communique, the Reagan administration sent Taipei "Six Assurances" in which Washington promised to; not to revise the TRA, not force negotiations between Peking and Taipei, or stop arms sales 


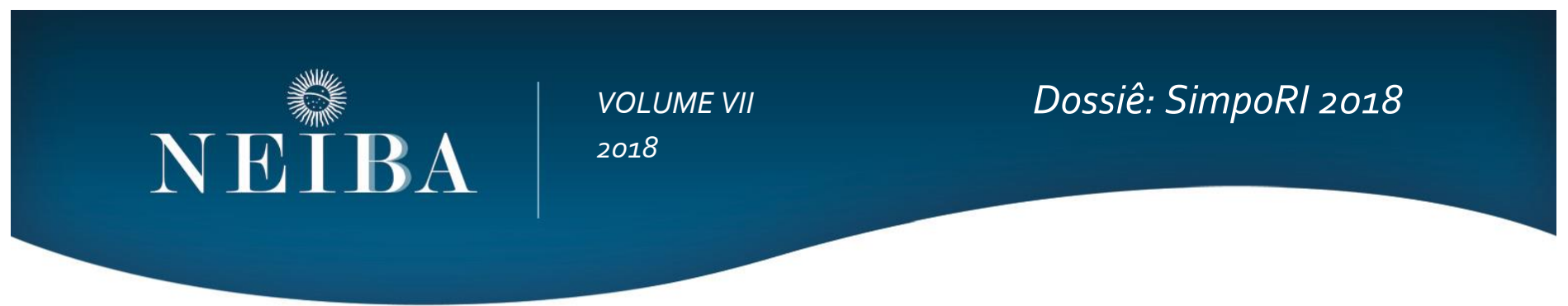

to the ROC (TSAI, 2009, p. 194-200). The three US-PRC joint communiques, the TRA, and the "Six Assurances" form the foundation of the US's ambiguous "One China Policy", or its Taiwan Policy, since the 1980's.

The exemplification of America's "One China Policy" could be observed during the 1990's, after Lee Teng-hui assumed the presidency of the ROC in 1988. During the Lee administration, Taipei continuously refusedto negotiate unification with Peking, and it extensively tried to promote the re-entry of the ROC in the UN, which prompted accusations by Peking of the UN promoting Taiwanese independence. In retaliation, the PRC launched several missiles tests against Taiwan's coast in 1995-1996, a few months before the ROC's first direct presidential elections, in an attempt to intimidate the ROC's electorate. In response, the US, in accordance with the provisions of the TRA, sent two aircraft to the Taiwan Strait in 1996 to block Peking from invading Taiwan. This incident is known as the "Third Taiwan Strait Crisis".

In order to relax US-PRC relations, in 1998, president Bill Clinton declared publicly the "Three No's" policy, in which the US did not support Taiwan independence, "Two Chinas", nor "One China, One Taiwan". The ambiguous stance of the Clinton administration was in accordance with the "One China Policy" andwas strategically adopted in order to prevent any threat to the status quo. However, the election of Chen Shui-bian from the DPP, who publicly supported Taiwanese independence, further increased tensions between the ROC and PRC, forcing Washington to intervene in Taiwan in order to prevent a conflict in the Taiwan Strait.

\section{Confronting China, "Supporting" Taiwan (2001)}

After being elected president in 2000, Che Shuibian, who openly declared himself in favor of Taiwanese independence, adopted a moderate tone regarding the PRC during his first two years in the presidency, avoiding provocation ofthe PRC. On the other hand, after George W. Bush became president of the US in 2001, he abandoned the US's cooperative stancetoward the PRC that had been adopted underhis predecessor Bill Clinton. According to the Republican Party's neoconservative view, the PRC was seen as a potential threat to the US. Consequently, Bush reassumed the traditional policy of contention and confrontation toward the PRC, which had been adopted by previous Republican administrations, including those of Ronald Reagan and George W. H. Bush. As part of this hostile policy, the Bush administration started to show public support of Taiwan(CLARK, 2006, p. 130-131).

In March 2001, soon after assuming office, Secretary of State Colin Powell told Senator Jesse Helms that the "Six Assurances" still remained in the US's policy toward Taiwan (KAN, 2007, p. 28). In April 2001, in the midst of the SinoAmerican crisis following the "Hainan Incident"1" , Bush authorized a package of sophisticated arms sales to the ROC (CARPENTER, 2004, p. 3). On 25 April, Bush publicly declared his government supported the defense of the ROC:

Well, I think that the Chinese must hear that ours is an administration, like other administrations, that is willing to uphold the spirit of the Taiwan relations law, Taiwan Relations Act... But as people have seen, that I'm willing to help Taiwan defend herself, and that nothing has really changed in policy, as far as I'm concerned. This is what other presidents have said, and I will continue to say so.... I have said that I will do what it takes to help Taiwan defend herself, and the Chinese must understand that. (KAN, 2011, p. 66)

\footnotetext{
${ }^{1}$ On April 1st, 2001, two military airplanes from the US and the PRC collided during patrol exercises in the Chinese Southern Sea and had to make an emergency landing in Hainan province (NYT, 2001).
} 


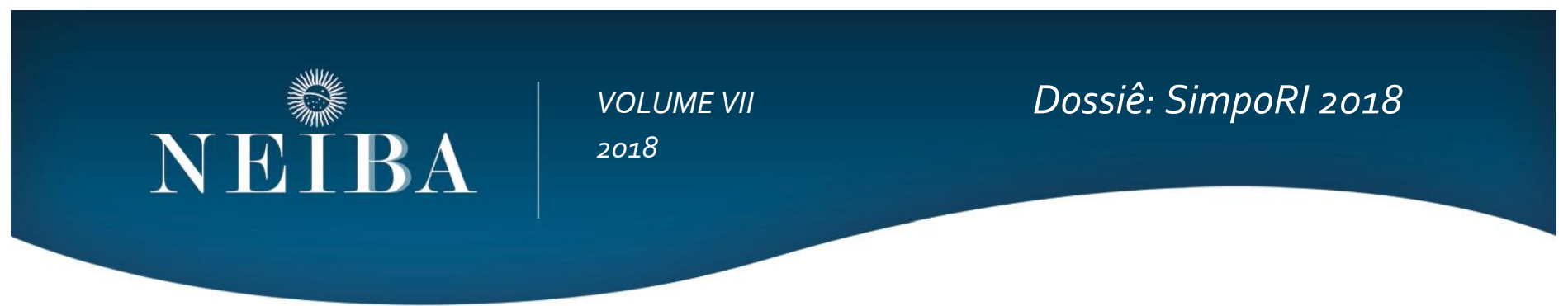

During his first year in office, Bush resumed US-ROC military exchanges that had been interrupted at the severing of diplomatic ties between the two countries in 1979. In 2001, Admiral Dennis Blair, Commandant in Chief of the US Pacific Command, made a secret visit to Taiwan, the firstofficial to visit Taiwan since 1979. The same year, American military officers assisted ROC's Hankuang ${ }^{2}$ annual exercises. In 2002, the US and ROC militaries established a hotline to deal with possible crisis. In 2003, the Hankuang exercises saw the secret participation of 19 American military officers. In March2002, the ROC's deputy defense minister Kang Ninghsiang visited the US, where he met the US' deputy secretary of defense Paul Wolfowitz and secretary of state assistant James Kelly (KAN, 2011, p. 5).

In addition, under Congress's lobby, in October 2002, Bush sanctioned "The Foreign Relations Authorization Act of 2002", through which the ROC earned a status similar to that of a "major non-NATO ally"3 : "for purposes of the transfer or possible transfer of defense articles or defense services under the Arms Control Act, the Foreign Assistance Act, or any other provision of law, Taiwan shall be treated as though it were designated a major non-NATO ally." The act also allowed the US to appoint personnel from other departments, such as defense, to the AIT (KAN, 2011, p. 5).

The long-term prohibition on contact between US and ROC officials was also relaxed during this period. In May 2001, while travelling to Latin America, Chen made a stopover in the US, where he met several American congressmen and also had a call with the deputy secretary of state Richard Armitage (KAN, 2011, p.14). Later, while on an official visit in Panama, Chen met briefly with secretary of state Collin Powell (KAHN, 2003). Nevertheless, although Bush adopted several pro-ROC measures during his first year

\footnotetext{
${ }^{2}$ Han-kuang Yan-hsi are annual military exercises conducted by the ROC since 1984, which simulate a possible invasion of Tawain by the PRC. 3 Major Non-NATO Ally is a term designated by the United States to refer to non-NATO strategic allies such as Australia, Egypt, Israel, Japan, Jordan, Argentina, the Republic of Korea, and New Zealand.
}

of government, he maintained the "One China Policy" in the US's Taiwan policy:

I certainly hope Taiwan adheres to the one China policy. And a declaration of independence is not the one China policy, and we will work with Taiwan to make sure that that doesn't happen(KAN, 2011, p. 66).

\section{Growing Radicalism and the Washington Concerns (2002-2003)}

Although Chen had adopted a conciliatory speech during his first two years in office, this suddenly ended in 2002, when he publicly defined cross-strait relations as "One China, One Taiwan". From then on, Chenpromotes Taiwaneseindependence from the ROC, through a constitutional reform to change the official name from the ROC to the "Republic of Taiwan". He also promoted "rectification" and "Taiwanization" policies , exacerbating cross-strait tensions. Although the DPP did not hold a majority position in the legislature, in 2003, the legislative approved the referendum law, allowing the president to call a "defensive referendum" in case of a threat to national sovereignty, which was denounced by Peking as a separatist maneuver, with Peking threating Taiwan with war in the case of independence (BUSH, 2005, p. 222-223; CARPENTER, 2004, p. 3).

The Bush administration initially demonstrated a favorable bias toward Chen's government. However, due to the terrorist attacks of September 11, the North-Korean nuclear crisis, and military operations in the Middle East, the Bush administration started to seek closer cooperation with the PRC to deal with these issues (TSAI, 2009, p. 204). ITheUS now needed to be more stable in the Taiwan Strait, so that the "Taiwan" factor did not interfere with Sino-US cooperation. In February 2002, during a meeting with the president of the PRC Jiang Zemin, Bush adopted a cautious position by stating: "We believe in the peaceful settlement of 


\section{NEIBA}

this issue. We will urge there be no provocation. The United States will continue to support the Taiwan Relations Act." (KAN, 2011, p. 67).

In August 2002, President Chen Shui-bian surprised the Bush administration when Chen did not consult the US before defining the relationship in the Taiwan Strait as "one country on each side." To calm the situation, Chen sent the minister of the Mainland Affairs Council Tsai Ingwen's president to Washington, where she met with deputy secretary of State Richard Armitage and Assistant Secretary of State James Kelly. Tsai assured that the policy toward RPC was not changed (SNYDER, 2002). In October 2002, during a meeting with Jiang, Bush made the following declaration:

I emphasized to the President that our one China policy, based on the three communiques and the Taiwan Relations Act, remains unchanged.I stressed the need for dialoguebetween China and Taiwan that leads to a peaceful resolution of their differences.... The one China policy means that the issue ought to be resolved peacefully. We've got influence with some in the region; we intend to make sure that the issue is resolved peacefully and that includes making it clear that we do not support independence (KAN, 2001, p. 68).

Hoping to persuade the Bush administration, in June 2003, Chen sent the Foreign Minister Eugene Chien to the US, where he met with Vice-President Dick Cheney (CNA, 2003). However, the Bush administration opposed the referendum, fearing that the referendum could affect USPRC relations. In December 2003, the National Security Council director James Moriarty met secretly with Chen and delivered a personal letter from Bush. During the meeting, Moriarty expressed the US's concern regarding Chen's "provocations" and Washington's dissatisfaction with recent statements (KNOWLTON and ITH, 2003). On 9 December
2003, during the visit of the PRC Premier Wen Jiabao to the US, Bush stated:

The United States Government's policy is one China, based upon the three communiques and the Taiwan Relations Act. We oppose any unilateral decision by either China or Taiwan to change the status quo. And the comments and actions made by the leader of Taiwan indicate that he may be willing to make decisions unilaterally to change the status quo, which we oppose(KAN, 2011a, p. 71).

\section{The American Warning}

In March 2004, despite his administration's poor economic and political performance, Chen was reelected president by a narrow margin of votes. Soon after this victory, the DPP aimed its efforts at wining the legislative elections of December 2004, in order to proceed with the constitutional reform plans, even after Washington'slowprofile warnings and refusal to approve the constructional reform plans. Facing Chen's insistence on independence rhetoric, and his provocative speeches against the PRC, soon after Chen's reelection, the White House issue the following statement.

The United States does not support independence for Taiwan or unilateral moves that would change the status quo as we define it. For Beijing, this means no use of force or threat to use force against Taiwan. For Taipei, it means exercising prudence in managing all aspects of cross strait relations. For both sides, it means no statements or actions that would unilaterally alter Taiwan's status... The United States will fulfill its obligations to help Taiwan defend itself, as mandated in the Taiwan Relations Act... Our 


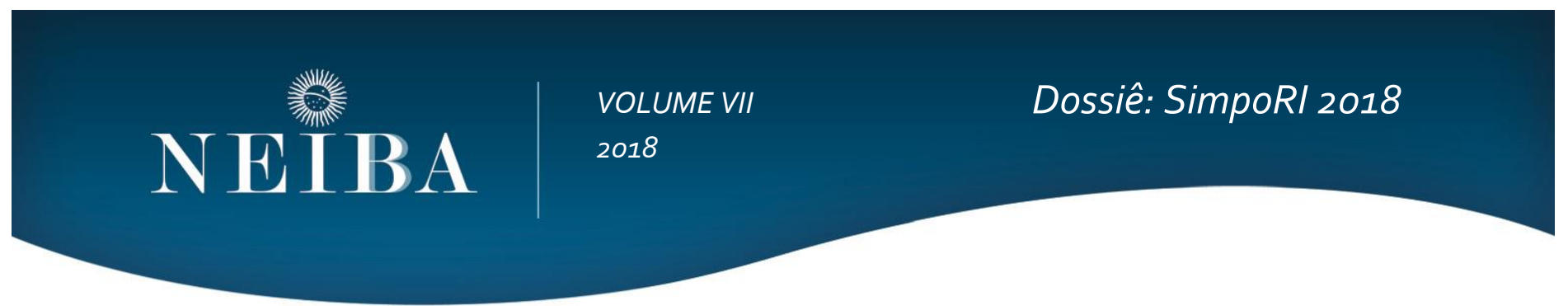

position continues to be embodied in the socalled "Six Assurances" ... We continue to urge Beijing and Taipei to pursue dialogue as soon as possible through any available channels, without preconditions. (KAN, 2011a, p. 72-73)

In April 2004, just before his inauguration, Chen sent Secretary General Chiou I-jen to Washington, where he met with Deputy Secretary of State Richard Armitage to try to convince the Bush administration of the constitutional reform plans, assuring that he would not change the official name, flag, or sovereignty. However, the plan was vetoed by the Bush administration again (CHEN and LIN, 2004). Facing the possibility of the DPP winning the legislative elections and the insistence of Chen, on 25 October 2004, as a sign of the US's irritation, Secretary of State Colin Powell stated:

There is only one China. Taiwan is not independent. It does not enjoy sovereignty as a nation, and that remains our policy, our firm policy... And that is why we think it is a policy that should be respected and should remain in force and will remain in force, on the American side, it is our policy that clearly rests on the Three Communiques. To repeat it one more time: we do not support an independence movement in Taiwan. (KAN, 2011a, p. 74)

Although the DPP loosed the legislative elections of December 2004, Chen's actions increased cross-strait tensions. The PRC ratified the "Anti-Secession Law" in March of 2005, which "allowed" Peking to use "non-pacific" means to prevent any attempt of Taiwaneseindependence. The law was immediately condemned by the international community, including Washington. Although President Bush hadreaffirmedthe US's promiseto defend Taiwan, he made a reservation:
We're for a One China policy based upon what they call the Three Communiqués, and that we adhere to the Taiwan Relations Act, which means this: Neither side will unilaterally change the status quo... If China were to invade unilaterally, we would rise up in the spirit of Taiwan Relations Act. If Taiwan were to declare independence unilaterally, it would be a unilateral decision that would then change the U.S. equation. (KAN, 2011, p. 74)

\section{American Retaliations}

Even after the DPP lost the legislative elections, which prevented Chen frompassingthe constitutional reform, Chen kept his same provocative stancetowards the PRC, publicly stating his desire for Taiwanese independence. In February 2006, the Department of State was surprised by a statement by Chen, in which he declared his wish to abolish the National Unification Council and proposed the admission of the ROC in the UN under the name "Taiwan". The US government immediately alerted Chen that he had to consult with Washington before making such an announcement, and it sent the director of the National Security Council Dennis Wilder to Taipei to try to convince Chen to give up the idea. However, Chen was resolute (SNYDER, 2006).

With Chen's refusal to follow Washington's advice, the Bush administration took several retaliation measures. In May 2006, when Chen applied for a transit visa in the US during his visit to Latin America, Washington allowed him to transit only in Honolulu and Anchorage, outside of the continuous US (KAN, 2011, p. 14). The Bush administration also opposed measures by the House of Representativesto facilitateofficial contact between US and ROC officials in 2006, alsoobstructingthe sale of the F16C/D to Taiwan. During a meeting with the president of the PRC Hu Jintao in 2006, Bush stated: "I assured the president [Hu] my position has not changed, I do not support independence for Taiwan" (KAN, 2011, p. 76). 


\section{NEIBA}

Chen's provocative stances worsened after he and his family suffered several corruption accusations. In order to distract public opinion, he adopted a radical stance regarding Taiwanese independence. During the last two years of his administration, Chen adopted several radical policies: he played the "ethnic card", which increased unnecessarily ethnic tensions in Taiwan. His administration changedthe names of several state-owned enterprises from "China" to "Taiwan". He also declared his idea of a "Second Republic". All of these actions were criticized by Washington, which publicly condemned Chen's provocations. In 2007, after Chen's administration announced pretentions to pass a referendum regarding Taiwan's application for UN membership, Washington issued the following statement:

The United States opposes any initiative that appears designed to change Taiwan's status unilaterally. This would include a referendum on whether to apply to the United Nations under the name Taiwan. While such a referendum would have no practical impact on Taiwan's U.N. status, it would increase tensions in the Taiwan Strait. Maintenance of peace and stability across the Taiwan Strait is of vital interest to the people of Taiwan and serves U.S. security interests as well... We urge President Chen to exercise leadership by rejecting such a proposed referendum (KAN, 2011, p. 77).

Despite Chen's adopted radical strategy, he was unable to control the loss of his popularity due to corruption scandals. Furthermore, his government failed to achieve several goals, resulting in a poor economic and political performance, a growing economic dependence on the PRC, and growing income inequality and wage stagnation. Beside it, Chen remained internationally isolated, since Washington and Peking publicly supported the KMT, who promised to stabilize the cross-strait relations, against the DPP in the 2008 legislative and presidential elections.
During the legislative elections of January 2008, the DPP suffered a landslide defeat when the party was only able to elect 27 congressmen to a total of 113 seats. Meanwhile, the KMT elected 81 congressmen. On March2008, Chinese mainland candidate Ma Ying-jeou (KMT) was elected president of the PRC, winning $58.45 \%$ of the vote against $41.55 \%$ for Frank Hsieh (DPP). The referendum convened on the day of the election by Chen, referring to the use of the name "Taiwan" to try to rejoin the UN, was invalidated. After the KMT victory, President George W. Bush sent the following message to Taiwan:

I congratulate the people of Taiwan on the successful conclusion of their March 22 presidential election. Once again, Taiwan has demonstrated the strength and vitality of its democracy... Taiwan is a beacon of democracy to Asia and the world... It falls to Taiwan and Beijing to build the essential foundations for peace and stability by pursuing dialogue through all available means and refraining from unilateral steps that would alter the cross-strait situation.... The maintenance of peace and stability in the Taiwan Strait and the welfare of the people on Taiwan remain of profound importance to the United States... We will continue to maintain close unofficial ties with the people on Taiwan through the American Institute in Taiwan in accordance with our long standing "one China" policy, our three Joint Communiques with the People's Republic of China, and the Taiwan Relations Act. (SNYDER, 2008)

\section{Conclusion}

Since the 1950's, the main purpose of the US's Taiwan policy was pure maintenance of the status quo in the Taiwan Strait. The US changed its policy towards the PRC in the 1970's, sacrificing Taipei's interests. Yet Washington never complete sold out Taiwan to Peking, due to 


\section{NEIBA}

Taiwan'sgeopolitical importance. The island of Taiwan, as well South Korea, Japan, Australia, and New Zealand, are extremely important to the maintenance of American hegemony and security, isolating the PRC in continental Asia. Any loss could mean the beginning of the end of the Pax Americana in the region.

Unlike the US's interventions in the Taiwan Strait during the 1950s, where the main purpose was to prevent the PRC's invasion of Taiwan, American intervention during the 200os were carried out with the purpose of preventing a unilateral change to the status quo by Taiwan. The US acted against Chiang Kai-shek during the 1950 s and 1960s, when Chiang insistently lobbied Washington to support his plan to invade mainland China and "unify" China under the ROC. His attempts were refused due to America's fear of launching another Korean War, and possibly dragging the Soviet Union into war.

During the Bush administration (2001-2009), the US acted against Taiwaneseindependence. Since 2001, Washington prioritized relationswith the PRC, due to the US's need to work with Peking in dealing with the North
Korean nuclear crisis, and to focus US diplomacy on military operations in the Middle East. Taiwan was a bargaining chip amidst these considerations. When the "troublemaker" Chen attempted to formalize Taiwan's independence, this action was seen by the US as "unnecessary" and extremely harmful for US-PRC relations. When Chen refused to stop his provocative actions against Peking, Washington was forced to act fiercely against him, in order to punish him, please the PRC, and consequently maintain the status quo in the Taiwan Strait.

The case study of Bush's Taiwan policy during the 2000 illustrates how the US's Taiwan policy did not change from the 1950s, but remained the same, not only to prevent the PRC from changing the status quo, but also as a strategy to prevent the ROC from changing it. For the US, the risk of going to war with the PRC by supporting Taiwanese independence was too costly. What is more, maintaining the status quo in the TaiwanStrait suitedAmerica's objective of keeping Taiwan under its sphere of influence. Later US administrations, such as Obama's and Trump's, continued this policy, keeping Taiwan as a bargaining chip and without a voice of its own. 


\section{NEIBA}

VOLUME VII

Dossiê: SimpoRI 2018

\section{8}

\section{BIBLIOGRAPHY}

Bush, R. (2005). Untying The Knot: Making Peace in Taiwan Strait. Washington, Brooking Institution Press, 2005.

Carpenter, T.G. (2005). America's Coming War with China. Basingstoke, Palgrave Macmillan, 2005.

Central National Agency (CNA) (2003). Foreign minister to rub shoulders with top US brass. Taipei Times, last modified in 22 June, 2003. Available in http://www.taipeitimes.com/News/taiwan/archives/2003/06/22/2003056272 (accessed I November, 2018)

Chen, M., and Lin, C.Y. (2004). Armitage presses Chen to reaffirm 'five noes' pledge. Taipei Times, last modified in 01 May, 2004. Available in http://www.taipeitimes.com/News/taiwan/print/2004/05/01/2003138729 (accessed 1 November, 2018)

Clark, C. (2003). Lee Teng-hui and the Emergence of a Competitive Party System in Taiwan. In: LEE, W.C. (Org). Sayonara to the Lee Teng-hui Era: Politics in Taiwan, 1988-2000. Lanham, University Press of America, 2003, p. 91-113.

Kan, S. (2001). China/Taiwan: Evolution of the "One China" Policy—Key Statements from Washington, Beijing, and Taipei. Congressional Research Service, 7-5700, RL30341.

Knowlton, B. and International Herald Tribune (IHT). Bush warns Taiwan to keep status quo: China welcomes U.S. stance. New York Times, last modified in 10 December, 2003. Available in https://www.nytimes.com/2003/12/10/news/bush-warns-taiwan-to-keepstatus-quo-china-welcomes-us-stance.html (accessed I November, 2018)

Snyder, C. (2002). US reacts to 'one country on each side'. Taipei Times, last modified in og august, 2002. Available in http://www.taipeitimes.com/News/front/archives/2002/08/og/o0o0159534 (accessed I November, 2018)

. (2006). US officials hint at meeting with Chen. Taipei Times, last modified in 24 February, 2006. Available in

http://www.taipeitimes.com/News/taiwan/archives/2006/02/23/2003294244 (accessed 1 November, 2018)

(2008). Presidential election 2008: Reaction: US President praises Ma, Taiwan following election. Taipei Times, last modified in 23 March, 2008. Available in http://www.taipeitimes.com/News/taiwan/archives/2008/03/23/2003406751 (accessed in 1 November, 2018).

Taiwan Affairs Office. (1993). The Taiwan Question and Reunification of China. Taiwan Affairs Office \& Information Office, State Council, August 1993. last modified in 14 October, 2003. Available in http://www. china-un. org/eng/zt/twwt/t28913.htm (accessed in 1 November, 2018).

Tsai, H. (2009). Maritime Taiwan. Armonk, M.E. Sharpe, 2009. 